\title{
Research on Strengthening the Resumption Construction of the People's Congress
}

\author{
Juan Qiao \\ College of Law \\ Sichuan University \\ Chengdu, China
}

\begin{abstract}
The People's Congress is an important part of China's political system and an important way to realize the modernization of the national governance system and governance capacity. As a key component of the people's congress, the ability of deputies to perform their duties determines whether they can assume the democratic rights to represent the broad masses of the people, promote the continuous innovation and development of the work of the NPC, and strengthen the party's ability to govern and the major political responsibility of the state's governance standards. However, there are some problems such as lack of quality ability, lagging platform construction, lack of supervision mechanism and weak service guarantee. China can learn from the advanced experience of the countries in the world and combine the specific national conditions of China to carry out institutional innovation. By optimizing the electoral mechanism, increasing the proportion of full-time representatives, deepening the performance training, grasping the platform construction, and strengthening the supervision and management of representatives, China can promote the better performance of the representatives.
\end{abstract}

Keywords-people's congress; deputies to people's congress; resumption

\section{INTRODUCTION}

The 18th National Congress of the Communist Party of China proposed "supporting and guaranteeing the people's exercise of state power through the people's congress." The Third Plenary Session of the 18th CPC Central Committee further proposed that "it is necessary to promote the people's congress system to keep pace with the times. It is also necessary to adhere to the people-centered principle, promote the theory and practice innovation of the people's congress system, and give play to the role of the people's congress system as the fundamental political system of China." Since the 18th National Congress of the Communist Party of China, General Secretary $\mathrm{Xi}$ Jinping has delivered a series of speeches and discussions on adhering to and improving the people's congress system and developing socialist democracy. General Secretary Xi Jinping's thinking on upholding and perfecting the people's congress system is an important part of Xi Jinping's socialism with Chinese characteristics since the new era.

The people's congress system is China's fundamental political system. The deputies of representatives of people's congress are the main components of the people's congress, and can be described as an important part of indirect democracy. The unsatisfactory performance of the people's congress deputies will directly lead to the people's congress system not being able to truly realize its sollen value.

\section{PROBLEMS IN THE PROCESS OF PERFORMANCE OF DEPUTIES TO THE PEOPLE'S CONGRESS}

Almond said: "The basic unit of political structure is the individual role. A role is a regular pattern of behavior that consists of the expectations and behaviors of people and others." ${ }^{1}$ In the sociological sense, the meaning of a role is a behavioral pattern associated with a particular location, and the role points to the individual's position in society. The role also reflects people's expectations of the individual's behavior in society. ${ }^{2}$ It can be seen that the role of deputies to the people's congress in the normative sense mainly exists in the institutional space of the Constitution and related laws. In the constitutional and legal context of China, the role of the deputies to people's congress in the normative sense is to be a representative of the will of the people and a member of the members of the state power. But in practice, the role of deputies to people's congress is not entirely in the vacuum of institutional space. The performance of deputies on behalf of the people's congress is often influenced by the actual political environment, political culture, and the interpretation of the role of the deputies to the people's congress themselves. Therefore, in practice, the normative role of the deputies to the people's congress is constantly changing, and even the basic value orientation of the role will change.

Whether the deputies to the people's congress can exercise state power in accordance with the responsibilities entrusted by the Constitution and the law is related to whether the wishes of the broad masses of the people can be correctly expressed and whether the principle of the sovereignty of the people can be realized. With the continuous advancement of the rule of law in the country and the improvement of citizens' overall demands for democracy,

Gabriel Almond Powell, Comparative Politics: Systems, Processes, and Policies [M] Cao Peilin, etc. trans. Shanghai: Shanghai Translation Publishing House, 1987.

Ding Shuimu, A Brief Discussion on the Role Theory of Sociology and Its Practical Significance, Journal of Shanghai University (Social Science Edition), 1987 (3) 
the requirements for the performance and performance of deputies to the people's congress are getting higher and higher, but the performance of NPC deputies at all levels, especially during the intersessional period, is not satisfactory. The reasons are mainly concentrated in the following aspects.

\section{A. The Role of the Deputies to the People's Congress Is Unclear}

Some deputies are not clear about their responsibilities and regard their representative status as an honorary title for their outstanding work performance. They never realize that the representative identity is rooted in the trust and expectations of the people. In some places, even there has been "anecdote" that the factory director, as the deputy to the people's congress, sent a secretary to participate in the representative activities, which is thought-provoking. ${ }^{3}$ The representative is undoubtedly glorious, but this does not mean that representing the status is only an honor. It is more about embodying the connotation of national duties. Unlike the members of the Western countries, the deputies to the people's congress of China do not face the "threat" of their political career. In addition, most of them are part-time representatives, and their time and energy are limited, resulting in low willingness to perform their duties.

\section{B. Disadvantages of Deputies' Part-time System}

The United Kingdom is the first country in the world to adopt a parliamentary system and a full-time parliamentary system. In the famous "Independence Law of the Throne" (1701), it is stipulated that "anyone who holds a senior position in the kingdom cannot become a member of parliament." Later, it added, "If the civil servant intends to participate in the election, he must resign his former occupation before his first competition speech." With the gradual development of the British constitutional monarchy, these regulations have gradually formed a complete system of full-time members of parliament; the first article of the US Federal Constitution also has such a provision: "Members of the Senate and House of Representatives cannot be appointed as any civil servant position within their national jurisdiction to set or increase their wages during the current term. Any person who holds a national public office cannot serve as a member of the Senate and House of Representatives while continuing his serve in national public office." Article 77 of the "Swiss Federal Constitution" states: "Members of the Federal Council and officials appointed by the Federal Council cannot simultaneously serve as members of the National Assembly." The full-time parliamentarian system has played a good role in promoting political civilization, social stability and normal order in Western representative countries.

China has a large number of part-time representatives from all walks of life. However, with the development of society, its shortcomings gradually emerged. The part-time deputies to the people's congress are mainly based on their own profession. The representative work is only a "side job",

Xie Hongzhang, The Problems and Countermeasures of the Deputies of the People's Congress, People's Congress Studying, 2004 (2). which leads to conflicts of time and energy between the representative position and the job. In addition, the representative status under the part-time system has duality. Their own responsibilities and interests may interfere with the performance of their duties, especially when they perform their supervisory duties, they often "avoid the important and dwell on the trivial" on the issues that are of interest to the department, thereby reducing the objectivity and impartiality of the representative's performance.

\section{Lack of Representatives' Quality and Ability}

Under the representative system, the public does not need to bear the "rational burden", they hand over this burden to the representatives. ${ }^{4}$ In fact, one of the reasons for the "transfer burden" is that not every ordinary citizen has enough wisdom, knowledge and ability to make rational decisions, so the masses of the people need the power to make decisions - that is, the "burden" was transferred to the representative. In other words, in order to properly perform their duties, deputies to the National People's Congress should have higher abilities and qualities than the general public. ${ }^{5}$

For a long time, China has always emphasized the election of representatives from advanced figures or model workers in all walks of life. Emphasizing its broad representation, paying too much attention to the "whole composition" of the gender, age, and ethnic groups of the deputies to the people's congress and neglecting its own ability to participate in political affairs, leads to the lack of research capacity of some representatives affecting the collection of public opinion, the lack of expression ability affecting the reflection of public opinion, the lack of coordination ability affecting the development of performance activities, and the lack of legal knowledge affecting the performance of duties.

\section{Lagging Behind the Construction of the Representative Work Platform}

Under the current conditions of the short-term and parttime system of the Chinese people's congress, the deputies to the people's congress can obtain a small amount of autonomy during the NPC session. Their participation in various representative activities during the intersessional period is an important part of fulfilling their duties and is also close. The main ways to contact the masses and supervise the promotion of government work can reflect their performance to a greater extent.

The 18th National Congress of the Communist Party of China put forward the "establishment of representative liaison institutions", emphasizing the strengthening of the NPC Standing Committee and NPC deputies, and giving full play to the role of deputies. It is necessary to consider

\footnotetext{
$4 \quad$ Refers to Lu Renyan, Thoughts on Enhancing the Consciousness of Representatives, Shandong People's Congress Work, 2006 (7).

$5 \quad$ Refers to Lang Youxing, Lu Man, Research on the Effectivenes of People's Congress Representative Workstation to Improve Representatives' Performance, Journal of Zhejiang Provincial Party School
} 2015 (5) 
establishing a well-established representative liaison organization and network platform to closely represent the relationship with the broad masses of the people. However, at present, the construction of workstations for grassroots people's congresses is relatively lagging behind. Most of the delegates use traditional methods such as seminars and visits. It is not common to use modern information means to help represent activities. At the same time, the regional gap is large in aspects of the information platform development, the effective use of new media, etc. The representative website is not active, it is not updated for a long time, and the problem of unreasonable setting of the board is more prominent.

\section{E. Lacking Supervision Mechanism of the Representative}

1) Lacking a democratic electoral system: Since whether the deputies to the people's congress can be reelected relies more on official decisions, voters and electoral units lack understanding of their representatives' performance, and there is no awareness and means of supervisory representatives. It is even more difficult to reward or punish their performances, resulting that there is no inevitable connection between the deputies of people's congress and their ability to re-elect.

2) Lacking the representative supervision mechanism: The provisions of the current law are not specific enough, and supervision lacks the necessary forms and means. In China's Constitution, election law and representative law stipulated the principle of "the deputies to the people's congress accept the supervision of the electorate of the original constituency or the original electoral unit". However, the relevant provisions are very general and too principled, there is no clear legal procedure, and there is no real binding regulation for specific supervision. As a result, there are no specific standards for the performance of the delegates, and there is little interest in whether or not to perform their duties, which has led to the "devious situation" that voters are difficult to achieve by supervising and recalling the deputies to the people's congress.

3) Imperfect representative performance incentive mechanism: Due to the imperfect incentive mechanism, the representatives with outstanding performances have no sense of honor, and the representatives with poor performance also have no shame, which affects the enthusiasm and initiative of the delegates for their duties.

\section{ENHANCING THE RESUMPTION ABILITY CONSTRUCTION OF THE DEPUTIES TO THE PEOPLE'S CONGRESS}

\section{A. Optimizing the Election Mechanism}

1) Improving the nomination and inspection mechanism of the deputies to the people's congress: The existing nomination mechanism pays too much attention to the structure and symbolism of the representatives. It is necessary to improve the nomination mechanism for deputies at all levels, especially the recommendation mechanism for candidates of the deputies to the people's congress. Grassroots party organizations should attach importance to the excavation and mobilization of party members in non-leadership positions with good mass base and ability to participate in politics, and strive to make candidates who are suitable for the job and suitable for the relevant positions become members of the state power organs.

2) Introducing a voluntary registration system for candidates: At present, the candidates for deputies to the people's congress are mainly recommended by political parties and social organizations, rather than the voters themselves. The generation of candidates for deputies to the people's congress should adopt a combination of organizational recommendations and individual declarations, encourage voters to recommend themselves, and motivate representatives to volunteer to serve the people, from "people want me to be a representative" to "I want to be a representative." It will also be important to pay attention to the multi-stakeholders, absorb the outstanding figures and activists who have grown up in the reform, and ensure the broadness of the representatives in order to realize the rationalization of the representative structure.

3) Increasing transparency in deputies' elections: Many scholars have repeatedly argued that campaigning is the best way to motivate voters - it can enhance the quality of elections, and ultimately generate representatives of the people's congresses who are responsible to the people. ${ }^{6}$ Arranging candidates to meet with voters, candidates can also introduce their detailed information to the voters through modern media such as the Internet and television, thereby enhancing communication between candidates and voters. Voters can cast their own sacred votes on the basis of a deeper understanding of the candidates. ${ }^{7}$

\section{B. Gradually Increasing the Proportion of Full-time Deputies}

The full-time deputies not only have long enough meeting time to discuss the proposals to avoid being "rubber stamp", but also have enough time to contact the voters, which shows self-evident advantages. "The socialist market economy naturally requires socialist democracy to match it. Democratic politics is not only the inevitable result of the market economy, but also the guarantee mechanism of the market economy." Since the reform and opening up, China's market economy has developed rapidly, the people's democratic consciousness has continuously improved, and many new situations and new problems have emerged. The need to adjust political, legal and other systems has become more urgent in order to provide guarantees for economic

6 Refers to Cai Dingian, On the Reform and Perfection of NPC System, Tribune of Political Science and Law, 2004 (6).

Refers to Zhou Ying, Research on the Questionnaire System of the People's Congress, Journal of The Party School of The Central Committee of The C.T.C, 2014 (4).

Refers to Yang Guangbin, Democratic Politics Is the Guarantee Mechanism of the Market Economy, People's Tribune, 2007, (11). 
development and to provide better support for people's masters. This means that the trend of professionalization has become "the hope of the public".

At present, most scholars have similarities in the proposals for relevant reforms - that is, no matter what path is taken, the ultimate goal is to make all the deputies to the people's congress fully-time appointed. In this regard, the author does not fully agree. Representative part-time system does require reform, but full-time and part-time jobs have their own strengths, which are necessary to be dialectically treated. The overall reform idea of combining full-time and part-time work can be adopted. That is, the representatives of ordinary people's congresses still maintain the status quo, and only the full-time reform of the Standing Committee of the National People's Congress can be implemented. Because in theory, a part-time representatives is indeed more representative than a few full-time representatives, and can prevent bureaucracy and representative "politician" tendencies to a certain extent, so as to maintain a pragmatic style. From a practical point of view, China has a population of 1.3 billion. Maintaining an appropriate number of deputies to the people's congress can maintain sufficient representation. This is what the national conditions require. However, at present, there is nearly 3 million people's congress deputies at all levels in the country. If all of them are full-time, not only the quality talents directly engaged in production and labor in various industries will be greatly reduced, but the huge financial burden will also make the country unbearable.

As far as the NPC Standing Committee is full-time, the Party Central Committee has always had a clear policy direction. As early as 1982, Comrade Peng Zhen, Chairman of the Standing Committee of the National People's Congress pointed out: "China has a vast territory and a large population. The number of the deputies to the people's congress should not be too small; but the number is large, and it is not convenient for regular work. Therefore, properly expanding the powers of the Standing Committee of the National People's Congress is an effective way to strengthen the people's congress system ${ }^{9}$." "We hope that the Standing Committee of the National People's Congress will go to fulltime. $^{10,}$

Of course, the specialization of the Standing Committee of the National People's Congress is not simply a matter of fully appointing the NPC Standing Committee. It is necessary to carry out institutional innovation at the same time as it goes full-time. China can learn from the common practices of parliaments around the world, establish a personal studio for the full-time members of the Standing Committee of the National People's Congress, equip them with assistants and necessary funds, and gradually establish a new set of work systems. And through the strengthening the

9 Selection of Important Documents of the People's Congress System, Beijing: China Democracy and Legal Publishing House, Central Literature Publishing House, 2012. 568 - 569.

10 Luo Shuyong, On the Specialization of Members of the Standing Committee of the National People's Congress, People's Congress Studying, 2012, (12). connection between the Standing Committee of the National People's Congress and the deputies to the people's congress, it can complement the "short board" of the part-time system.

\section{Improving the Relevant Laws of the Deputies to the People's Congress}

The current Constitution, Organic Law, and Representative Law only have the principled provisions for the performance of the deputies to the people's congress. The "Implementation Measures" should be formulated according to the actual situation of each locality to make it more operational. Taking Beijing as an example, the Beijing Municipal People's Congress has formulated and improved the "Implementation Measures" and "Regulations" in a timely manner in accordance with relevant laws. The practice and innovative experience of the people's congress system has been consolidated in the form of local legislation, thus providing legal support for the performance of duties, and providing a useful exploration for promoting the NPC system to keep pace with the times. This has reference to other local people's congresses. ${ }^{11}$

\section{Strengthening Representative Resumption Training}

This includes carefully formulating learning plans, rationally setting training content, comprehensively applying various forms, training the knowledge that the representative should master, and making clear requirements for the content of duties that should be performed. In particular, emphasis should be placed on improving the level and ability of delegates to write and discuss proposals.

At the end of the training, the examination should be carried out. Those who fail to meet the standards should be retaken for examination. The training and examination results must be included in the representative's personal files.

\section{E. Improving the Construction of Representative Resumption Platform}

1) Construction of the deputies to the people's congress to contact the people's work platform: The representative group is an important form of the activities of the deputies to the people's congress during the intersessional period. However, the fact that China's administrative regions are large and the representatives are scattered has made it difficult for delegates to perform their duties during the intersessional period. The emergence of the deputies to the people's congress workstation provides an effective way to solve this problem.

Taking Wenling in Zhejiang as an example, the representative workstation effectively overcomes the difficulties that the deputies to the people's congress are difficult to convene during the intersessional period. At the same time, the activities on behalf of the workstations have effectively enhanced the overall quality and performance of the representatives, and cultivated and enhanced the

11 Xu Yongli, Yang Jitang, Beijing Legislative Exploration with the Performance of the Deputies to the People's Congress, Journal of Beijing University (Humanities and Social Sciences), 2014, (2). 
representative's sense of responsibility and sense of role identification. $^{12}$

It is recommended to establish a "workstation of representative to contact the masses of the people" at the township level. Deputies to people's congresses at all levels use the workstation as a platform to contact the people, to ensure the full coverage of the site construction within the jurisdiction, and realize the normalization of the connection between the representatives and the people. At the same time, the county and township people's congresses should select the staff, which are familiar with the grassroots situation for the platform, and gradually establish a volunteer team to conduct investigations and research for the representatives and provide services to the people.

However, it is necessary to clarify the subjective nature of the deputies to the people's congress workstation. In practice, based on the coordination concept of modern management, districts, streets and representative liaison stations integrate similar functions, and after the cooperation of letters and visits, people's mediation, judicial mediation and representative visits, the government is in a strong position, which eventually leads to the fact that the letters and visits become bigger and become the actual leader. It can be said that the cart before the horse is upside down. It is necessary to pay attention to the fact that the deputies to the people's congress liaison station are bigger and stronger, so that it can resolve the people's livelihood demands. ${ }^{13}$

2) Building a resumption network platform of the deputies to the people's congress: With the rapid development and widespread popularity of information technology, the influence of online political participation on representative systems has gradually expanded. Toffler once predicted: "Information is closely related to power and thus to politics. As we enter the age of information politics, this relationship will become closer and closer. ${ }^{14 "}$

Judging from the current situation, the E-Committee and the E-proposal have been widely recognized. For the first time in the Proposal for the Eleventh Session of the 11th National Committee of the Chinese People's Political Consultative Conference, the "E-Proposal Selection" from the People's Daily Online Power Forum has showed. The symbolic meaning is that the voice of netizens enters from the virtual cyberspace to the real decision-making level. ${ }^{15}$ The current representative law does not stipulate that the EProposal can be directly translated into the deputies to the people's congress proposal. However, with the continuous

12 Refers to Lang Youxing, Lu Man, Research on the Effectiveness of People's Congress Representative Workstation to Improve Representatives' Performance, Journal of Zhejiang Provincial Party School, 2015 (5).

13 Refers to Zhou Changxian, Practice Exploration of People's Congress Representatives' Contacting Community System Construction, Expanding Horizons, 2012 (4).

14 Alvin Toffler, Toffler's Work Selection, Dalian: Liaoning Science and Technology Publishing House, 1984: 9.

15 Refers to Mo Sangxin, Huang Daxi, The Deputies to People's Congress' "Working Online" Dilemma and a Countermeasure Discussion, Journal of Hunan University (Social Sciences), 2017 (6). maturity of the practice experience of the E-Two-sessions associations, it can be institutionalized and regulate the behavior of netizens participating in political discussions.

In 2016, the Shanghai Municipal People's Congress took the lead in launching the "Shanghai Representatives Resumption" APP, providing an innovative model for the resumption of deputies to the people's congress in the Internet era. ${ }^{16}$

The above successful experience can be referred to adapt to the current "Internet + " trend, create "online people", "smart people's congress", all-day online representative contact station, and "network through train", so that to achieve real-time representation of the contact service, 24 hours "do not close," and to take the online mass line. It is also necessary to establish network public opinion collection, research and judgment, and interactive mechanisms, broaden the channels for connecting with the people, and effectively open up the "last mile" of representing and serving the masses, and realize the seamless connection between the people's demands and the state power organs, which make it possible to make citizens participate in the legislative work of the NPC in an orderly manner.

\section{F. Strengthening the Supervision and Management of Deputies to the People's Congress}

According to Olson's collective action logic, collective action is prone to free-riding behavior in the absence of incentives and constraints. This dilemma also exists in the resumption of the deputies to the people's congress. In practice, part of the reason for the inefficient operation of the power of the people's congress is that it represents the performance of its duties. Only effective supervision of it can make collective action more efficient, thus avoiding the negative inaction of the deputies to the people's congress. "Supervising the status of the executive duties is an important way for the people to promote the management of the state affairs and is also the embodiment of the people's sovereignty. ${ }^{17 "}$

1) Adhering to and promoting the deputies to the people's congress to accept the deliberation system: In this regard, the deliberative review activities of parliamentarians in Taiwan can be used for reference. Zhu Hengshun believes that as long as the meeting does not involve state secrets, citizens should be allowed to listen and the media should be free to interview and open to the whole society through television, radio and internet. At the same time, the deputies of the people's congress will disclose the work of the individual to the voters in various ways. ${ }^{18}$ In short, no matter what method is adopted, it should reflect the

16 Refers to Liu Xinlu, "Shanghai Representative Resumption" APP "Upgrade", Youth Daily, Mar. 2, 2016.

17 Qiao Xiaoyang, The National People's Congress of the People's Republic of China and the Local People's Congress, Beijing: People's Publishing House, 2010.

18 Refers to Zhu Hengshun, The Open Resumption information Makes the Deputies to the People's Congress No Longer "Absent", People's Congress Studying, 2011 (4). 
principle of openness and transparency, make the work of the representative be carried out in the sun and be supervised by the people.

It may be considered to produce a "descriptive list" each year by the constituency. The deputies to the people's congress on the list will report to the voters, and organize the voters to conduct a written review of the debriefing or vote by secret ballot to achieve supervision of the deputies to the people's congress.

In 2016, the Jiangbei District People's Congress of Chongqing Municipality will stipulate the resumption of deputies of the people's congress as 11 items as "participating in the district people's congress", "proposing proposals and suggestions", "attending the Standing Committee of the People's Congress", and "participating in the performance supervision, inspection, investigation and other performance supervision activities organized by the Standing Committee of the District People's Congress" etc., and corresponding assignment scores. ${ }^{19}$ This provides a good demonstration.

2) Constantly improving the construction of the performance files of deputies to the people's congress: Dynamic management of delegates attending meetings, participating in activities and carrying out work situation should be carried out. It should also combine with the performance of the resumption of the representative to carry out the selection of outstanding people's congress representatives' activities.

3) Making the performance of the deputies to the people's congress during the intersessional period public: Lenin once praised the openness of the Soviet regime: "This regime is open to everyone. It handles everything in the face of the masses... without any privacy and secrets. ${ }^{20}$ " However, the current focus of China's people's congress law focuses on the work of the people's congress during the meeting, while ignoring the performance of the deputies to the people's congress during the intersessional period. Without the supervision of the open mechanism, there is no way to talk about it. Therefore, an open system for the performance of duties during the intersessional period should be established to guarantee the right of the majority of voters to know and supervise.

4) Establishing and improving the exit mechanism of the deputies to the people's congress: China's "Election Law" and "Representative Law" clearly stipulate that the people not only have the right to vote and be elected, but also the right to dismiss the deputies to the people's congress. Jurisprudentially, the right to vote is an authorization act for the representative, and the recall is an act of reclaiming the authorization. Both of them are constitutional rights, and the manifestation of the sovereignty of the people, which the

19 Chongqing Jiangbei People's Congress Representative Performs the "Points System", The Beijing News, 2016, June, 14.

20 The Collected Works of Lenin: Vol. 10, Beijing: People's Publishing House, 1958: 214 - 215. constitutional principle pointed that "all power belongs to the people", and naturally they have the same legal status. ${ }^{21}$

However, this part is only a principled provision, without detailed procedures, lack of operability, resulting in almost no practical examples of the removal of deputies to the people's congress initiated by voters. ${ }^{22}$ Coupled with the fact that voters do not understand the resumption of deputies to the people's congress, it is not easy to be known if they do not perform their duties seriously and it makes supervision impossible. Cai Dingjian believes that strengthening supervision over the delegates and performing their duties in accordance with the law is an important part of perfecting the people's congress system and developing socialist democracy. Under the existing imperfect legal provisions, it is difficult for voters to realize the supervision of the deputies to the people's congress. It is necessary to make the people's congress and representative activities public. ${ }^{23}$

Relevant mechanisms should be established to increase the accountability of the so-called "three nonrepresentatives" - people's congress representatives who do not represent their obligations, do not actively participate in meetings and activities, and do not make suggestions. It is necessary to launch the advice on representatives who have not performed their duties for a long time to enhance the sense of responsibility and urgency for the deputies' resumption.

\section{G. Perfecting and Consolidating the Protection of the Rights of Deputies}

At present, the system has clarified that the deputies to the people's congress enjoy the economic rights such as performance remuneration, the democratic rights such as the exemption of speech, and the protection of the rights of the special protection of the person, so as to eliminate the "worries" for the performance of the duties. However, in order to make the representative's resumption more effective and practical, the representative's right to know must be fully guaranteed. Compared with individuals, the government has a natural advantage in grasping the comprehensiveness, and accuracy and timeliness of information. The degree of mastery of the national conditions and social conditions is one of the most important factors in all the factors that the representatives can effectively perform their duties. Therefore, how to balance the protection of the right to know and the preservation of state secrets and respect for the privacy of citizens is subject to further careful consideration.

\footnotetext{
21 Wang Quanfa, Thoughts on Perfecting the Dismissal System of Grassroots People's Congress, People's Congress Studying, 2012, (1).

22 Wang Yijiu,The Status Quo of the Performance of the Representatives of the Grassroots People's Congress, the Causes of the Problems and the Countermeasures - Taking the Representative Group of the People's Congress in Wuligou Area, Huaiyin District, Ji'nan City as an Example, People's Congress Studying, 2010 (3).

23 Cai Dingjian, Exploration of a NPC Researcher, Wuhan, Wuhan University Press, 2007: 429 - 430.
} 


\section{CONCLUSION}

The system of people's congress is China's fundamental political system and fully reflects the principle of people's sovereignty. The deputies to the people's congress are an important part of the people's congresses at all levels. They come from the people and represent the people. Their performance in performance is directly related to whether the constitutional principle of "all power belongs to the people" can be realized. It is of far-reaching significance to strengthen the performance of the deputies to the people's congress through the construction and improvement of relevant systems.

\section{REFERENCES}

[1] Gabriel Almond Powell, Comparative Politics: Systems, Processes, and Policies $[\mathrm{M}]$ Cao Peilin, etc. trans. Shanghai: Shanghai Translation Publishing House, 1987. (in Chinese)

[2] Ding Shuimu, A Brief Discussion on the Role Theory of Sociology and Its Practical Significance [J] Journal of Shanghai University (Social Science Edition), 1987 (3): 49 - 54. (in Chinese)

[3] Xie Hongzhang, The Problems and Countermeasures of the Deputies of the People's Congress [J] People's Congress Studying, 2004 (2). (in Chinese)

[4] Lu Renyan, Thoughts on Enhancing the Consciousness of Representatives [J] Shandong People's Congress Work, 2006 (7). (in Chinese)

[5] Lang Youxing, Lu Man, Research on the Effectiveness of People's Congress Representative Workstation to Improve Representatives' Performance [J] Journal of Zhejiang Provincial Party School, 2015 (5). (in Chinese)

[6] Cai Dingjian, On the Reform and Perfection of NPC System [J] Tribune of Political Science and Law, 2004 (6). (in Chinese)

[7] Zhou Ying, Research on the Questionnaire System of the People's Congress [J] Journal of The Party School of The Central Committee of The C.T.C, 2014 (4). (in Chinese)

[8] Yang Guangbin, Democratic Politics Is the Guarantee Mechanism of the Market Economy [J] People's Tribune, 2007, (11): 47. (in Chinese)

[9] Selection of Important Documents of the People's Congress System [M] Beijing: China Democracy and Legal Publishing House, Central Literature Publishing House, 2015, 568 - 569. (in Chinese)

[10] Luo Shuyong, On the Specialization of Members of the Standing Committee of the National People's Congress [N] People's Congress Studying, 2012, (12): 6. (in Chinese)

[11] Xu Yongli, Yang Jitang, Beijing Legislative Exploration with the Performance of the Deputies to the People's Congress [J] Journal of Beijing University (Humanities and Social Sciences), 2014, (2). (in Chinese)

[12] Zhou Changxian, Practice Exploration of People's Congress Representatives' Contacting Community System Construction [J] Expanding Horizons, 2012 (4). (in Chinese)

[13] Alvin Toffler, Toffler's Work Selection [M] Dalian: Liaoning Science and Technology Publishing House, 1984: 9. (in Chinese)

[14] Mo Sangxin, Huang Daxi, The Deputies to People's Congress' "Working Online" Dilemma and a Countermeasure Discussion [J] Journal of Hunan University (Social Sciences), 2017 (6). (in Chinese)

[15] Liu Xinlu, "Shanghai Representative Resumption" APP "Upgrade" [N] Youth Daily, 2016, Mar. 2. (in Chinese)

[16] Qiao Xiaoyang, The National People's Congress of the People's Republic of China and the Local People's Congress [M] Beijing: People's Publishing House, 2010. (in Chinese)

[17] Zhu Hengshun, The Open Resumption information Makes the Deputies to the People's Congress No Longer "Absent" [J] People's Congress Studying, 2011 (4). (in Chinese)
[18] Chongqing Jiangbei People's Congress Representative Performs the "Points System" [N] The Beijing News, 2016, June, 14. (in Chinese)

[19] The Collected Works of Lenin: Vol. 10. [M] Beijing: People's Publishing House, 1958: 214 - 215. (in Chinese)

[20] Wang Quanfa, Thoughts on Perfecting the Dismissal System of Grassroots People's Congress [J] People's Congress Studying, 2012 (1): 35 - 39. (in Chinese)

[21] Wang Yijiu,The Status Quo of the Performance of the Representatives of the Grassroots People's Congress, the Causes of the Problems and the Countermeasures - Taking the Representative Group of the People's Congress in Wuligou Area, Huaiyin District, Ji'nan City as an Example [J] People's Congress Studying, 2010 (3). (in Chinese)

[22] Cai Dingjian, Exploration of a NPC Researcher [M] Wuhan, Wuhan University Press, 2007: 429 - 430. (in Chinese) 